\title{
OD VIZUALIZACIJE DO ELIMINACIJE MISKONCEPATA
}

\author{
Snježana Smerdel \\ Prirodoslovno-matematički fakultet Sveučilišta u Splitu \\ Split, Hrvatska
}

\begin{abstract}
Sažetak:
Istraživanja na području kemijskog obrazovanja pokazala su da učenici ulaze u učionice s unaprijed stvorenim predodžbama o prirodi, različitim od onih koje nudi postojeća znanstvena teorija i praksa. Nastavnici žele da učenici shvate relevantnost kemije za njihov svakodnevni život, ali mnogo je primjera nastavnih situacija bez praktičnog iskustva. Modernu kemiju karakterizira učenje i razmišljanje koje se odvija u stalnom prijelazu između makroskopske, submikroskopske i simboličke razine prikaza. Kada učenici ne mogu povezati sve tri razine, znanje im je fragmentirano i mnoge koncepte vjerojatno su naučili samo na činjeničnoj razini. Submikroskopska interpretacija na razini škole teško se može dostići promatranjem i eksperimentalnim učenjem, ali razvojem moderne informacijske tehnologije upravo animirana vizualizacija postaje moćni alat za poučavanje i učenje kemije. Prikladno odabrani i primijenjeni dinamički vizualni prikazi poput animacija i simulacija pomažu učenicima vizualizirati procese i poboljšati konceptualno razumijevanje kako bi mogli izgraditi znanstveno prihvatljive mentalne modele tvari i reakcija na submikroskopskoj razini.
\end{abstract}

Ključne riječi:animacije, dinamička vizualizacija, kemijsko obrazovanje, mentalni modeli, miskoncepti, simulacije

\section{UvoD}

Od kada je u ranim 1800-tim godinama kemija postala nastavni_predmet u srednjim školama, kemičari su usmjereni na tri osnovna pitanja: što učenici trebaju znati, razumjeti i biti u mogućnosti učiniti, kako to postići te kako ćemo znati jesu li su ti ciljevi postignuti. Nesposobnost učenika da povezuju važne biološke procese i ključne kemijske koncepte, primjerice atome, molekulske strukture, svojstva tvari, termodinamiku i kemijske reakcije u velikoj je mjeri rezultat poučavanja kemije. Nastavnici žele da učenici razumiju kako je kemija relevantna za njihov svakodnevni život, ali mnogo je primjera nastavnih situacija u kojima nemaju praktično iskustvo. To im otežava povezivanje kemije sa svakodnevnim životom i s drugim disciplinama te ih potiče da ograniče kemijske pojmove na kemijsku učionicu.

Istraživanja pokazuju da prijenos podataka iz jednog konteksta u drugi pojačava prezentiranje nastavnog materijala pomoću različitih medija. Primjenom tehnologije u učionici i laboratoriju znatno se može poboljšati učenje, laboratorijski podaci mogu biti prikupljeni u kratkom vremenskom periodu te pomoću računala i grafičkih kalkulatora interpretirani u obliku smislenijem za učenike. U modernoj kemiji programi za vizualizaciju usmjeravaju se na kreiranje $i$ manipulaciju dinamičkih prikaza molekulskih struktura koje je inače teško vizualizirati (Lowery Bretz, 2009). 


\section{Proces uČENJA KEMIJE}

Johnstone je 1982. godine predložio da u kemiji treba razmišljati na makroskopskoj (opažačkoj), submikroskopskoj (čestičnoj) i simboličkoj (reprezentativnoj) razini (Slika 1). Makroskopska razina uključuje kemiju koja je vidljiva i opipljiva i sve ono što možemo percipirati osjetilima, dok submikroskopska razina sadrži mentalne slike kojima se kemičari koriste za zamišljanje i objašnjavanje opažanja na razini atoma, iona i molekula. Opažene pojave i procesi na submikroskopskoj razini zapisuju se matematički i kemijski na simboličkoj razini.

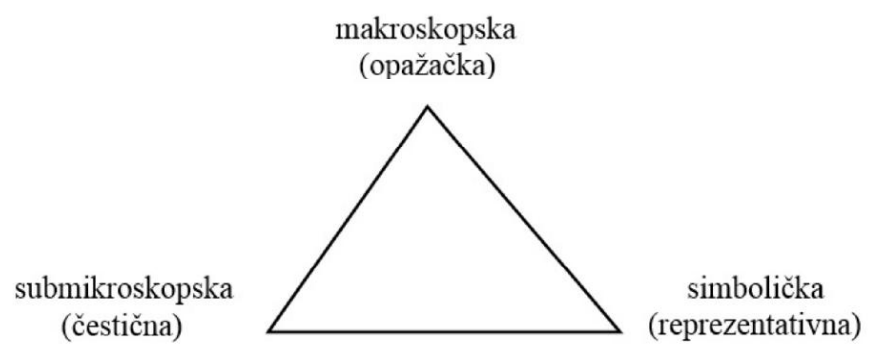

Slika 1. Razine poučavanja kemije (Johnstone, 1982)

Razumijevanje odnosa između tih triju razina razlikuje se od učenika do učenika bez obzira na akademski uspjeh. Kada ne mogu povezati razine prikaza, njihovo je znanje fragmentirano i mnoge koncepte vjerojatno su naučili samo na činjeničnoj razini. Prema konstruktivizmu pod učenjem podrazumijevamo proces aktivne izgradnje novih znanja čvrsto utemeljen na prethodnom znanju učenika. Primljene informacije obrađuju se u postojećim kognitivnim okvirima tako da se novoizgrađeno znanje pojavljuje kao konglomerat predznanja i svih novih dijelova informacija. Na proces učenja utječe i svakodnevno životno iskustvo učenika (Eilks, Witteck \& Pietzner, 2012).

\section{Mentalni modeli}

U znanstvenoj literaturi već se duže vrijeme nastoji opisati proces kojim učenici napreduju u razumijevanju temeljnih kemijskih koncepata kao i utvrditi progresija znanja, odnosno način na koji se razvija konceptualno razumijevanje sadržaja i pojmova. Učenici često ne mogu vizualizirati kemijske reakcije kao dinamičke procese u kojima se reakcijom čestica tvari stvaraju nove čestice tvari. Za rješavanje tog problema predloženo je korištenje konkretnih modela $i$ dinamičkih grafičkih prikaza molekularnih interakcija. To može pomoći razvijanju razumijevanja na razini čestica, no ne omogućuje se povezivanje s makroskopskom i simboličkom razinom prikaza kod svih učenika što ograničava razvoj odgovarajućih i cjelovitih mentalnih modela. Nerazumijevanje koje su iskusili mnogi početnici u učenju kemije jasno je povezano s njihovim netočnim mentalnim modelima (Garnet, Oliver \& Hackling, 1998). U obrazovnoj znanosti mentalni modeli okarakterizirani su analizom izraženih modela (Slika 2).

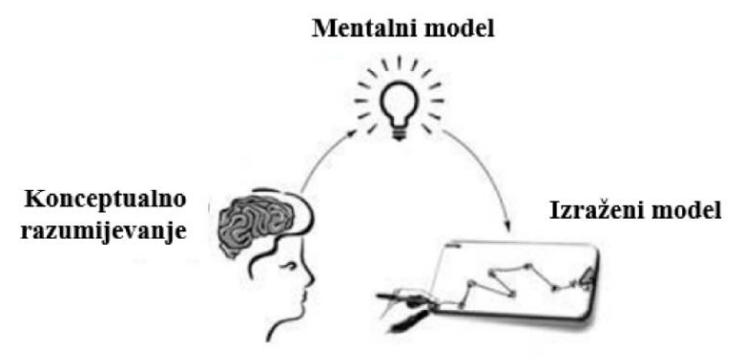

Slika 2. Prikaz odnosa između konceptualnog razumijevanja, mentalnog i izraženog modela (prilagođeno prema Stains, Escriu-Sune, Molina Alvarez de Santizo \& Sevian, 2011, str. 1361) 
Mentalni modeli osobni su kognitivni prikazi, dok izraženi modeli nastaju na temelju mentalnih modela koje učenici posjeduju i upućuju na njihovo konceptualno razumijevanje (Stains i sur., 2011). Kao važan cilj poučavanja i učenja razvoj točnih mentalnih modela uključuje reorganizaciju postojećih struktura znanja što je težak proces za učenike $s$ različitim tumačenjima i razumijevanjem istog događaja (Garnet i sur., 1998).

\section{Razvoj miskoncepata (alternativnih koncepata)}

Istraživanja na području kemijskog obrazovanja pokazala su da učenici ulaze u učionice s unaprijed stvorenim predodžbama o prirodi koja nas okružuje. Te se predodžbe razlikuju od onih koje nudi postojeća znanstvena teorija i praksa te proizlaze iz njihovih prethodnih osobnih i društvenih iskustava. Učenici se oslanjaju na "zdrav razum“ i nastoje bez mnogo razmišljanja stvoriti brza objašnjenja prirodnih pojava temeljena na intuiciji i uopćavanju. S obzirom da nastoje asimilirati nove informacije u postojeće strukture znanja, stvara se mnogo neželjenih obrazovnih ishoda. Takav obrazac razmišljanja inače nam omogućuje da pojednostavimo složeni svijet koji nas okružuje i vrlo je koristan u svakodnevnom životu jer često vodi do ispravnog rješenja, ne zahtijevajući veći intelektualni napor. Nažalost, zdravorazumsko razmišljanje, koje se oslanja na mentalne strategije odlučivanja i stvaranja zaključaka na lako dostupnim informacijama, odgovorno je za niz miskoncepata (alternativnih koncepata) kojih se držimo prilikom objašnjavanja svijeta koji nas okružuje, a nisu u skladu sa znanstvenim spoznajama (Talanquer, 2006).

Prema razvojnoj psihologiji postupak razmišljanja koji koristi prečace zvan heuristika, smanjuje ionako preopterećenu obradu informacija. Zadaća je takvog pristupa da se u okviru ograničenog vremena i znanja stvore razumne i primjenjive predodžbe o svijetu koje nisu nužno logične i suvisle. Obično se stvaraju prihvatljivi odgovori s malo uloženog napora, ali ponekad dolazi i do ozbiljnih predrasuda i pogrešaka. Primjerice, kada se dogodi nešto neočekivano, heurističko razmišljanje vodi nas do traženja uzroka u skorašnjem vremenu i prostoru, onom što nam je blisko i lako za prisjećanje. Različiti ljudi mogu na različite načine promišljati o nekoj pojavi i stvoriti različita objašnjenja, iako dijele isti konceptualni okvir i obrazac razmišljanja. Zdravorazumsko razmišljanje utemeljeno je na korištenju heuristike koja kontrolira kako i gdje potražiti željenu informaciju pri suočavanju s problemom, kada završiti s istraživanjem i što činiti s prikupljenim rezultatima. Ovaj način razmišljanja pruža različita objašnjenja i obrasce odlučivanja specifične za svakog pojedinca jer je uvjetovan specifičnim kontekstom problema i osobnim iskustvom (Talanquer, 2006).

Premda su prepoznavanje i klasifikacija pogrešnih učeničkih razmišljanja o prirodnim pojavama ključni u stvaranju znanstvenog pogleda na svijet, većina nastavnika ih ne analizira. Malo važnosti pridaju značenju odgovora učenika i često nisu u mogućnosti prepoznati dosljedan obrazac njihovog razmišljanja, premda bi analiza takvog obrasca mogla poslužiti kao ishodište za unapređenje procesa razumijevanja. Svojim istraživanjem Talanquer je želio utvrditi uobičajene pretpostavke o prirodnim pojavama i popratnim modelima zaključivanja na kojima leže mnogi kemijski miskoncepti opisani u znanstvenoj literaturi, uzimajući u obzir da su konceptualne poteškoće rezultat razmišljanja utemeljenog na „zdravom razumu“.

Razvoj i korištenje takvog „eksplanatornog okvira" koristio bi nastavnicima kemije da prepoznaju, razumiju pa čak i predvide moguće miskoncepte kod učenika. Prema rezultatima istraživanja predloženi eksplanatorni okvir temelji se na nizu empirijskih pretpostavki o svijetu koji nas okružuje (kontinuitet, supstancionalizam, esencijalizam, mehanička uzročnost, teleologija), korištenju brzog i skromnog heurističkog razmišljanja prilikom donošenja odluka (asocijacija, redukcija, fiksacija, linearni slijed) te donošenju zaključaka na temelju dostupnih informacija. Sustav znanja koji obuhvaća mnoge miskoncepte učenika opće kemije (Tablica 1) vjerojatno se ne odvija na svjesnoj razini i stvara privid eksplanatorne dubine: učenici vjeruju da razumiju mnogo više no što stvarno razumiju. 
Zdravorazumski učenik pretpostavlja sljedeće (Talanquer, 2006):

- sve su tvari sastavni dijelovi prirode, postoje i razvijaju se neovisno o opažaču

- tijela su onakva kakvim ih upažamo

- nešto postoji samo ako se može opaziti, što je tijelo manje dostupno osjetilima manje je materijalno

- tijela i materijali nastoje egzistirati u „prirodnom“ stanju (normalno inertno stanje), samo njihova neuobičajena svojstva i ponašanja zahtijevaju objašnjenje koje se treba zasnivati na opažanju

- modeli su malo nesavršeniji prikaz stvarnosti, stvarnost se može koristiti u objašnjavanju svojstava znanstvenih modela, modeli moraju biti vjerne kopije inače su nekorisni.

Tablica 1. Klasifikacija nekih uobičajenih miskoncepata u kemiji temeljenih na zdravorazumskom eksplanatornom okviru (Talanquer, 2006, str. 815)

\begin{tabular}{|c|c|}
\hline Empirijske pretpostavke & Miskoncepti \\
\hline Kontinuitet & $\begin{array}{l}\text { - atomi i molekule imaju makroskopska svojstva: oni se šire i gube na masi } \\
\text { kada se zagrijavaju, imaju ujednačene gustoće i točno određene boje, } \\
\text { mogu se kovati, mijenjati oblik pod tlakom itd. }\end{array}$ \\
\hline Supstancionalizam & $\begin{array}{l}\text { - toplina ima svojstva tvari i ponaša se kao fluid } \\
\text { - struktura kemijske veze je materijalna } \\
\text { - elektronski oblaci i ljuske građeni su od iste tvari }\end{array}$ \\
\hline Esencijalizam & $\begin{array}{l}\text { - hrđa je vrsta željeza } \\
\cdot \text { nemoguće je kemijski izlučiti ugljik iz plina }\left(\mathrm{CO}_{2}\right) \\
\text { - tvar se gorenjem nepovratno uništava }\end{array}$ \\
\hline Mehanička uzročnost & $\begin{array}{l}\text { - plin zauzima sav prostor u posudi zbog odbojnih sila među česticama } \\
\text { - sila koja pokreće kemijsku reakciju uvijek je vanjski činitelj } \\
\text { - kemijske reakcije uzrokovane su aktivnim tvarima koje djeluju na pasivne } \\
\text { tvari }\end{array}$ \\
\hline Teleologija & $\begin{array}{l}\text { - tvari reagiraju kako bi smanjile svoju energiju } \\
\text { - atomi dijele, primaju i predaju elektrone kako bi zadovoljili pravilo okteta } \\
\text { - molekule zauzimaju određeni oblik kako bi se umanjilo odbijanje među } \\
\text { vezama }\end{array}$ \\
\hline Heurističko razmišljanje & Miskoncepti \\
\hline Asocijacija & $\begin{array}{l}\text { - toplina je glavni uzročnik svih kemijskih reakcija } \\
\text { - zagrijavanjem sustava proporcionalno se povećava njegova temperatura } \\
\text { - miješanjem kiselina i baza nastaje neutralna otopina }\end{array}$ \\
\hline Redukcija & $\begin{array}{l}\text { - polarnost kemijske veze određuje oblik molekule } \\
\text { - ukupan broj elektrona određuje veličinu atoma } \\
\text { - intermolekulske sile vrsta su energije }\end{array}$ \\
\hline Fiksacija & $\begin{array}{l}\text { - entropija sustava uvijek raste } \\
\text { - kemijske promjene uvijek su ireverzibilne } \\
\text { - svi kemijski spojevi građeni su od molekula }\end{array}$ \\
\hline Linearni slijed & $\begin{array}{l}\text { - u ravnoteži unapredna reakcija završava prije početka unazadne reakcije } \\
\text { - u elektrokemijskom članku elektroni se kreću u krugu, uzrokujući linearni } \\
\text { slijed događaja } \\
\text { - reakcijski mehanizam odvija se tako da prvi korak mora završiti prije } \\
\text { početka sljedećeg }\end{array}$ \\
\hline
\end{tabular}

Analiza miskoncepata sa stajališta predloženog zdravorazumskog eksplanatornog okvira trebala bi pomoći nastavnicima u razvijanju i implementaciji nastavnih strategija koje unapređuju učenje i razumijevanje (Talanquer, 2006). 


\section{Prevladavanje miskoncepata u kemiji}

Modernu kemiju karakterizira učenje i razmišljanje koje se odvija u stalnom prijelazu između makroskopske, submikroskopske i simboličke razine prikaza. Ako su te razine i njihove interakcije pogrešno protumačene, pojavit će se znanstveno nepouzdana tumačenja. Kako je prethodno opisano, učenici na početku učenja uvijek pokušavaju koristiti objašnjenja stečena svakodnevnim životnim iskustvom što također može ometati učenje znanstveno prihvaćenih koncepata. Za prevladavanje miskoncepata znanstveni edukatori predlažu razvoj nastavnih strategija i materijala koji izazivaju „kognitivni sukob“ u učeniku. Ideja je da se znanstveno neprihvaćene ideje mogu prevladati uspoređivanjem s proturječnim dokazima, primjerice putem pokusa.

Nažalost, submikroskopska interpretacija na razini škole teško se može dostići promatranjem i eksperimentalnim učenjem. Zbog nevidljive prirode čestica, kemijsko obrazovanje bavi se submikroskopskom razinom najčešće na teorijskom pristupu primjenom znanstvenih modela kao što su statične ilustracije dostupne u svakom udžbeniku kemije. Proces učenja o modelima i njihovom ispravnom korištenju sam je po sebi težak zadatak. Međutim, razvojem moderne informacijske tehnologije, animirana vizualizacija postaje moćni alat za poučavanje i učenje kemije (Eilks i sur., 2012).

\section{VIZUALIZACIJA I MULTIMEDIJSKI IZVORI}

Vizualizacija ima dugu povijest uporabe u znanosti. Od Galilea, Descartesa, Newtona, Maxwella, Einsteina i mnogih drugih znanstvenika koji su se njome koristili pa sve do danas, vizualizacija pokušava prikazati znanstvene pojave koje su daleko od mogućnosti izravnog promatranja. U tumačenju interaktivnih vizualizacija objekata učenici se suočavaju s dva izazova, moraju razumjeti kako radi korisničko sučelje i veća je kognitivna zahtjevnost za njihovu memoriju nego kod statičnih slika (Braga, Phillips \& Norris, 2012).

\section{Mehanizmi vizualizacije}

Trenutno ne postoji niti jedna kognitivna teorija koja daje sasvim zadovoljavajuće objašnjenje mehanizma vizualizacije. Međutim, dvije su osnovne teorijske perspektive za djelomično objašnjenje nastajanja vizualizacije. Dvojaka komunikacijska teorija (engl. Dual-Coding Theory, DCT) utemeljena je na pretpostavci da se vizualne i verbalne informacije kodiraju i obrađuju zasebno te da će njihova istovremena pravilna primjena pridonijeti boljem zadržavanju informacija u odnosu na njihovu izoliranu uporabu. Druga tcorijska perspcktiva, pretpostavka vizual ne slike (engl. The Visual Imagery Hypothesis, VIH), smatra da se vizualne informacije mogu učinkovitije obrađivati od verbalnih jer su takve kognitivne transformacije manje zahtjevne za radnu memoriju učenika. To je bitno u kontekstu rješavanja problema gdje vizualni prikaz može biti učinkovitiji od verbalne potpore. Ove dvije kognitivne teorije nisu nužno međusobno kompatibilne, a njihovom sintezom formulirana je i treća teorijska perspektiva, pretpostavka združenog zadržavanja (engl. The Conjoint Retention Hypothesis, $\mathrm{CRH}$ ) primjenjiva u situacijama gdje se DCT i VIH teorije preklapaju (Braga, Phillips \& Norris, 2012).

lako nam empirijska istraživanja omogućuju uvid u učinke vizualizacije objekata u određenim obrazovnim kontekstima, posve općenita teorijska perspektiva s obzirom na prirodu vizualizacije ne pojavljuje se na horizontu. Phillips i sur. (2010) upozoravaju da nastavnici i znanstvenici trebaju koristiti raspoložive rezultate u kontekstu sličnom onom u kojemu su otkriveni jer ne postoje adekvatne teorije za određivanju njihove generalizacije u drugim situacijama (Braga, Phillips \& Norris, 2012). 


\section{Učenje s multimedijskim izvorima}

Tijekom protekla dva desetljeća provedena su mnoga istraživanja o tome kako ljudi uče $s$ multimedijskim izvorima i kako je to povezano s načinom izrade takvih resursa. $U$ tim istraživanjima u obzir se uzima uloga kognitivnog kapaciteta uz važnost dosljednih implikacija za izradu i korištenje multimedijskih izvora. Teorija koja se direktno odnosi na kognitivni kapacitet, teorija kognitivnog opterećenja (engl. Cognitive Load Theory, CLT) opisuje kako su obrada informacija i izgradnja znanja ograničeni radnom memorijom. $U$ određenom vremenu samo će mala količina informacija biti obrađena u radnoj memoriji dok prekomjerni zahtjevi rezultiraju preopterećenjem koje može otežati učinkovito zadržavanje informacija.

Na kognitivne procese uključene u učenje s multimedijskim izvorima odnosi se kognitivna teorija multimedijskog učenja (engl. Cognitivne Theory of Multimedia Learning, CTML) zasnovana na tri glavne pretpostavke. Pretpostavka dvostrukog kanala (engl. Dual Channel Assumption) sugerira da ljudi imaju odvojene kanale za primanje i obradu informacija, jedan za verbalne, a drugi za vizualne informacije. Primjena je te pretpostavke da pružanje informacija istovremeno kroz oba kanala može biti prednost za njihovo kodiranje i dohvat. Zatim, pretpostavka ograničenog kapaciteta (engl. Limited Capacity Assumption) upućuje da svaki kanal obrade ima ograničen kapacitet te da radna memorija učenika može zadržati samo mali broj riječi ili slika u danom momentu. Posljednja pretpostavka aktivne obrade (engl. Active Processing Assumption), tvrdi da ljudi nisu pasivni primatelji nastavnog sadržaja, već moraju aktivno sudjelovati u obradi dobivenih informacija, izgrađujući točne mentalne modele novih koncepata. Za proces izgradnje znanja učenici moraju odabrati relevantne vizualne i verbalne informacije iz materijala prezentiranih primjenom multimedije, organizirati informacije za izgradnju koherentnog vizualnog i verbalnog mentalnog prikaza te integrirati te prikaze s prethodnim znanjem (Schwartz, Milne, Homer \& Plass, 2013).

\section{VizUALIZACIJA U NASTAVI KEMIJE}

Nastavnici kemije imaju razvijene mentalne modele kemijskih pojmova i pojava koji omogućuju primjenu odgovarajućih pojmova i teorija na nove situacije. Kod učenika su ti modeli nepotpuni i nekonzistentni i često prikazuju znanstvene probleme u nepovezanim fragmentima. U novije vrijeme interaktivni vizualni prikazi imaju potencijal prevladati ograničenja tradicionalnih medija i podržati učenike u razvoju točnih mentalnih modela (Russell i sur., 1997).

\section{Dinamička vizualizacija}

Animacije i simulacije, kao oblici dinamičke vizualizacije, uključuju istovremeno prezentiranje višestrukih oblika prikaza uz interaktivno razjašnjavanje njihove povezanosti. Udružuju se pokret i promjena čime se učenicima pruža mogućnost vizualizacije koncepata, pojava i procesa koji nisu vidljivi ili su teško razumljivi. Za učenike to nije samo prenošenje informacija već podrška aktivnom učenju koje im daje mogućnost da prepoznaju obrasce kroz vlastito istraživanje (Schwartz i sur., 2013). Tasker i Dalton (2006) opisuju animacije i simulacije kao dinamički molekularni svijet učinkovitiji od statičnih slika i riječi jer su učenici pošteđeni kognitivnog opterećenja radne memorije.

Animacije su prikazi izrađeni kao serije slika za prezentiranje procesa i pojava u realnom vremenu ili usporeno kao i za objašnjavanje apstraktnih informacija, primjerice promjene tlaka ili odnosa između dviju varijabli. Korisniku se omogućuje da zaustavi, pokrene ili ponovi dijelove prezentacije dok vizualni znakovi usmjeravaju pozornost na specifične značajke. Pet je različitih 
funkcija animacija: napraviti predavanja atraktivnima, zadobiti pozornost, motivirati učenike te prezentirati i pojasniti informacije.

Simulacije su interaktivni prikazi pojava, procesa ili sustava koje korisnik istražuje, manipulirajući različitim parametrima. Moguće je postavljanje hipoteza, prilagođavanje varijabli unutar virtualnog okruženja kao i opažanje učinaka tih manipulacija. Osnova je svake simulacije model koji određuje kako sustav odgovara na upite korisnika i iz toga proizlazi interakcija kojom korisnik može doći do konceptualnog razumijevanja modela (Schwartz i sur., 2013).

\section{Prednosti i nedostaci dinamičke vizualizacije}

Učenje kroz vizualizaciju temelji se na semantičkom procesu koji može dovesti do uspješnog učenja samo ako je prikladno povezano s prethodnim znanjem i prikazuje znanstveni pojam na ispravan način. Oblik vizualizacije koji prikazuje razinu čestica pomaže učenicima u razumijevanju trodimenzionalne strukture i u razvoju prostornih sposobnosti, smanjuje mogućnost stvaranja novih miskoncepata o osnovnim kemijskim pojmovima te povećava motivaciju učenika za učenje kemije. Ponekad se pozitivni učinak može povećati ako učenici, na temelju dinamičkih vizualizacija, izrađuju vlastite crteže. Pored obećavajućeg potencijala postoji mogućnost da će se sjetiti što su vidjeli u animaciji i napravit će odgovarajuće crteže, ali neće nužno razumjeti ono što su vidjeli (Kelly \& Jones, 2007 u Eilks i sur., 2012).

Postoje i činitelji koji umanjuju uglavnom pozitivni potencijal dinamičkih vizualizacija pri učenju kemije kao što su zahtjevnije korištenje metakognitivnih sposobnosti, nedostatak predznanja učenika, precjenjivanje sposobnosti učenika da prepoznaju i koriste odgovarajuće prostorne odnose i neuzimanje u obzir njihove ograničene pozornosti pri gledanju animacija. Stoga, ako se primjenom vizualizacije u prirodoznanstvenom obrazovanju očekuje učinkovito učenje, vizualna pomagala moraju biti strukturirana prema predznanju učenika i određenoj temi gdje u obzir treba uzeti znanstveno prihvaćeno objašnjenje i izbor čestičnog modela (Eilks i sur., 2012).

Dinamički prikazi mogu poslužiti kao podrška učenicima u zadržavanju informacija (prisjećanje), shvaćanju informacija (razumijevanje) ili u primjeni informacija na novu situaciju (transfer) (Schwartz i sur., 2013). U usporedbi s koreografiranim animacijama, simulacije daju točniji prikaz struktura i procesa na submikroskopskoj razini, ali često ne pokazuju važne oblike reakcija s česticama, a ponekad molekule otapala blokiraju pogled na reakciju. Uzevši u obzir njihove prednosti i nedostatke, animacije i simulacije trebaju biti korištene za međusobno nadopunjavanje (Tasker \& Dalton, 2006). Detaljnije je razmotrena primjena animacija u eliminaciji miskoncepata i izgradnji znanstveno prihvatljivih mentalnih modela.

\section{ANIMACIJE U NASTAVI KEMIJE}

Istraživanja jasno pokazuju da mnoge poteškoće učenika i pogrešna shvaćanja u kemiji potječu iz njihove nesposobnosti da vizualiziraju strukture i procese na submikroskopskoj razini. Budući da je svijet čestica uvijek dinamičan, bilo bi razumno pretpostaviti da će animacije biti učinkovit medij za njegovo oslikavanje (Tasker \& Dalton, 2006).

\section{Kreiranje animacija}

Do početka 90-ih godina prevladavao je klasičan način proizvodnje animacija u 2D s tisućama izrađenih crteža fotokopiranih na film ili skeniranih na računalo koje je sudjelovalo samo u završnoj fazi proizvodnje. Razvojem računalnih programa animirana produkcija u cijelosti se izvodi na računalu. Pojavom računalnih programa za 3D modeliranje mogu se izgraditi vrlo precizni, gotovo stvarni objekti. Takve digitalne 3D animacije zahtijevaju veća ulaganja u 
početne faze modeliranja, ali kada je jednom 3D objekt stvoren, njime se može manipulirati stvaranjem pokreta, promjenom kutova prikazivanja reakcija, dimenzija, boja, zumiranjem na važne pojedinosti itd. (Fiscarelli, Bizelli \& Fiscarelli, 2011).

Tijekom proteklih nekoliko desetljeća teorijska i empirijska istraživanja predložila su i potvrdila niz načela za kreiranje takvih multimedijskih resursa. Za učinkovito kreiranje i implementaciju dinamičkih prikaza potrebno je poći od nekoliko pretpostavki. Prvo, prema CTMLteoriji pojedinci uče dublje ako nastavni materijali sadrže i riječi i slike što je za kemijsko obrazovanje osobito važno. Zatim, nastavni materijali moraju imati koherentnu strukturu koja će podržati učenike u izgradnji točnih mentalnih modela. I konačno, zbog ograničenog kapaciteta obrade, učenici ne mogu učinkovito obraditi veću količinu informacija (Schwartz i sur., 2013).

S druge strane, pri korištenju posebnih obrazovnih strategija važno je uzeti u obzir potrebe naprednih učenika. Takve učenike mogu ometati strategije koje inače pomažu učenicima nižih razina znanja. Slijedom toga, individualne karakteristike učenika važan su činitelj u kreiranju i odabiru dinamičkih prikaza za obrazovne svrhe. Pojedinci koji razvijaju animacije za kemijsko obrazovanje kao i oni koji ih odabiru i implementiraju za školsku uporabu, mogu se voditi navedenim pretpostavkama, premda nije moguće uspostaviti čvrsta pravila o tome kako osmisliti vizualne alate i kada se njima koristiti. Chandler (2004) je primijetio da nastavnici često čine ključnu pogrešku, dopuštajući da tehnologija stvara iskustva učenja, a ne da nas naše znanje o kognitivnim procesima vodi u što boljem korištenju tehnologijom u nastavne svrhe (Schwartz i sur., 2013).

\section{Primjena animacija}

Mentalni modeli učenika ne mogu se jednostavno mijenjati samo pokazivanjem drugačijih modela vizualizacije. Animacije na submikroskopskoj razini moraju biti uvjerljiv i učinkovit izvor za učenje s točno definiranim kemijskim sadržajem. Prezentiraju se u kratkim prikazima (20 s - 60 s) s velikom pažnjom kako se ne bi razvila nova pogrešna shvaćanja. Za učinkovitu primjenu animacija moramo usmjeriti pozornost učenika na glavne značajke, izbjegavati preopterećenje radne memorije mnoštvom novih informacija te promicati smislenu integraciju s predznanjem u okviru konstruktivističkog pristupa, koristeći se svojim znanjem o tome kako učenici uče.

Kako bi se učenicima pomoglo da povežu sve tri razine razumijevanja kemije, animacije treba prikazati tri puta. Prvo bez komentara uz poticanje da traže ključne značajke, zatim u kratkim sekvencama, usmjeravajući pozornost na važne značajke (smanjenje opterećenja radne memorije, integracija s prethodnim znanjem) i odgovaranjem na pitanja učenika te treći puta opet u cijelosti s ponovljenim, simultanim pripovijedanjem. Nakon toga, kratka diskusija u skupinama pomaže učenicima uočiti propuštene aspekte (Tasker \& Dalton, 2006).

Istraživanja sugeriraju da gledanje animacija pomaže učenicima vizualizirati procese, poboljšati konceptualno razumijevanje $i$ izgraditi znanstveno prihvatljive mentalne modele tvari i reakcija na submikroskopskoj razini (Sanger Phelps \& Fienhold, 2000; Williamson \& Abraham, 1995). Za poboljšanje konceptualnog razumijevanja učenika najučinkovitija je kombinacija animacija s demonstracijama nastavnika. Međutim, animacije su vizualno složenije od dijagrama što smanjuje njihovu učinkovitost, a dokazi upućuju da učenici mogu dobivene ideje prenijeti na slične situacije, ali ne i na nove teme te da postoji mogućnost izazivanja novih i otpornih miskoncepata (Tasker \& Dalton, 2006) kao i zadržavanje već postojećih (Smith \& Villarreal, 2015). 


\section{ZAKLUUČAK}

Izrada, odabir i korištenje dinamičke vizualizacije u kemijskom obrazovanju zahtijeva promišljeni pristup koji može biti koristan, ne samo zbog usmjeravanja na sadržaj i nastavne ciljeve već i zbog razumijevanja potreba pojedinih učenika i samog procesa učenja. Prikladno odabrana i primijenjena dinamička vizualizacija može biti učinkovita u stvaranju znanstveno prihvaćenih mentalnih modela. Autori udžbenika i interaktivnih materijala za učenje kao i nastavnici u kemijskom obrazovanju trebaju razmišljati o učinkovitijim načinima vizualizacije na razini čestica te prije svega dovoljno razraditi vlastito razumijevanje znanstvenih modela i njihove primjene.

Nastavnici trebaju biti svjesni ograničenja vizualizacije i kritični u uporabi jer vizualizirani sadržaj nije automatski razumljiv $i$ ispravno klasificiran. Nema sumnje da je većina takvih objekata privlačna pa je možda najčešća opasnost vizualizacije u oduševljavanju nekim sadržajima i traženju razloga da se uključe u nastavne materijale. U svakom slučaju, danas su vizualni alati u stanju unaprijediti koncepte učenja te njihov doprinos prirodoznanstvenom obrazovanju ne treba previdjeti.

\section{LITERATURA}

Braga, J., Phillips L. M. \& Norris, S. P. (2012). Visualizations and visualization in science education. In Norris, S. P. (Ed.), Reading for Evidence and Interpreting Visualizations in Mathematics and Science [ducation (pp. 123-145). Rotterdam: Sense Publishers.

Chandler, P. (2004). The crucial role of cognitive processes in the design of dynamic visualizations. Learning and Instruction, 14(3), 353-357.

Eilks, I., Witteck, T. \& Pietzner, V. (2012). The role and potential dangers of visualisation when learning about sub-microscopic explanations in chemistry education. CEPS Journal, 2 (1), 125-145.

Fiscarelli, S. H., Bizelli, M. H. S. \& Fiscarelli, P. E. (2011). Using 3D animations in teaching chemistry. Global Learn, 2011(1), 278-282.

Garnett, P., Oliver, R. \& Hackling, M. (1998). Designing interactive multimedia materials to support concept development in beginning chemistry classes. In Global Education ON the Net: Proceedings of the Sixth International Conference on Computers in Education (Vol. 1, pp. 297-304).

Johnstone, A. H. (1982). Macro and microchemistry. School Science Review, 64, 377-379.

Kelly, R. M. \& Jones, L. L. (2007). Exploring how different features of animations of sodium chloride dissolution affect students' explanations. Journal of Science Education and Technology, 16(5), 413-429.

Lowery Bretz, S. (Ed.) (2009). Chemistry in the National Science Education Standards: Models for Meaningful Learning in the High School Chemistry Classroom (2nd ed.). Washington, DC: American Chemical Society.

Phillips, L. M., Norris, S. P. \& Macnab, J. S. (2010). Visualization in Mathematics, Reading, and Science Education. London, UK: Springer.

Russell, J. W., Kozma, R. B., Jones, T., Wykoff, J., Marx, N. \& Davis, J. (1997). Use of simultaneoussynchronised macroscopic, microscopic, and symbolic representations to enhance the teaching and learning of chemical concepts. Journal of Chemical Education, 74(3), 330-334.

Sanger, M. J., Phelps, A. J. \& Fienhold, J. (2000). Using a computer animation to improve students' conceptual understanding of a can-crushing demonstration. Journal of Chemical Education, 77(11), 1517-1520.

Schwartz, R. N., Milne, C., Homer, B. D. \& Plass, J. L. (2013). Designing and implementing effective animations and simulations for chemistry learning. In Suits, J. P. \& Sanger, M. J. (Eds.), Pedagogic Roles of Animations and Simulations in Chemistry Courses (pp. 43-76). Washington, DC: American Chemical Society. 
Smith, K. C. \& Villarreal, S. (2015). Using animations in identifying general chemistry students' misconceptions and evaluating their knowledge transfer relating to particle position in physical changes. Chemistry Education Research and Practice, 16(2), 273-282.

Stains, M., Escriu-Sune, M., Molina Alvarez de Santizo, M. L. \& Sevian, H. (2011). Assessing secondary and college students' implicit assumptions about the particulate nature of matter: development and validation of the struclure and molion of maller

survey. Journal of Chemical Education, 88(10), 1359-1365.

Talanquer, V. (2006). Commonsense chemistry: a model for understanding students' alternative conceptions. Journal of Chemical Education, 83(5), 811-816.

Tasker, R. \& Dalton, R. (2006). Research into practice: visualisation of the molecular world using animations. Chemistry Education Research and Practice, 7(2), 141-159.

Williamson, V. M. \& Abraham, M. R. (1995). The effects of computer animation on the particulate mental models of college chemistry students. Journal of Research in Science Teaching, 32(5), 521-534.

\title{
From Visualisation to Elimination of Misconceptions
}

\begin{abstract}
Research in the field of chemistry education has shown that students enter the classroom with conceptions about the nature created in advance, different from those provided by the existing scientific theory and practice. Teachers want their students to understand the relevance of chemistry in their everyday life. However, there are many examples of teaching situations without practical experience. Modern chemistry is characterised by learning and reasoning which is carried out through a continuous transition between macroscopic, submicroscopic and symbolic level of presentation. When the students are not able to connect all three levels, their knowledge is fragmented, and they have probably learnt many concepts only at a factual level. Submicroscopic interpretation at the school level can hardly be reached through observation and experimental learning. However, with the development of modern information technology, animated visualisation becomes a powerful tool for teaching and learning chemistry. Conveniently chosen and applied dynamic visual presentations, such as animations and simulations, help students to visualise processes and improve conceptual understanding in order to build scientifically acceptable mental models of the matter and reactions at a submicroscopic level.
\end{abstract}

Keywords: animations, dynamic visualisation, chemistry education, mental models, misconceptions, simulations

\section{Von der Visualisierung bis hin zur Eliminierung von falschen Vorstellungen}

Zusammenfassung: Forschungen auf dem Gebiet des Chemieunterrichts deuten darauf hin, dass Schüler das Klassenzimmer mit vorgefassten Vorstellungen zur Natur betreten, die sich von der vorliegenden wissenschaftlichen Theorie und Praxis unterscheiden. Lehrer streben dazu, dass Schüler die Bedeutung von Chemie für ihr Alltagsleben begreifen, jedoch finden sich viele Beispiele von Unterrichtssituationen, die keine praktische Erfahrung bieten. Die moderne Chemie ist gekennzeichnet durch Lernen und Denken im ständigen Übergang zwischen der makroskopischen, submikroskopischen und symbolischen Darstellungsebene. Wenn Schüler nicht imstande sind, alle drei Ebenen zu verbinden, heißt das, dass ihr Wissen fragmentarisch ist und viele Konzepte vermutlich nur auf der Sachebene gelernt wurden. Die submikroskopische Auslegung ist auf Schulebene kaum durch Beobachtung und experimentelles Lernen zu erreichen. Jedoch wird durch Entwicklung der modernen Informationstechnik gerade die animierte Visualisierung zum mächtigen Werkzeug für Chemielehren und -lernen. Entsprechend ausgesuchte und verwendete dynamische visuelle Darstellungen wie Animationen und Simulationen helfen Schülern dabei, Prozesse zu visualisieren und ihr konzeptuelles Verständnis zu verbessern, und ermöglichen ihnen, wissenschaftlich akzeptable mentale Substanz- und Reaktionsmodelle auf der submikroskopischen Ebene aufzubauen.

Schlüsselbegriffe: Animationen, dynamische Visualisierung, Chemie lehren, mentale Modelle, falsche Vorstellungen, Simulationen 